\title{
TRAVEL BEHAVIOR OF COMMUTERS IN ASEAN COUNTRIES WITH THE LEAST CONFIRMED COVID-19 CASES DURING THE GLOBAL PANDEMIC - A CASE STUDY OF CAMBODIA AND LAOS
}

\author{
Sisalermkiat Phandanouvong ${ }^{1,2}$, Syed Muhammad Tariq Shah ${ }^{1,3}$, Monorom Rith ${ }^{1,2}$, \\ and Mongkut Piantanakulchai ${ }^{1{ }^{* *}}$ \\ ${ }^{1}$ School of Civil Engineering and Technology, Sirindhorn International Institute of Technology, \\ Thammasat University, Pathum Thani, Thailand, e-mail: sisalermkiatpdnv@gmail.com, \\ rith_monorom@yahoo.com, mongkut@ siit.tu.ac.th
}

\begin{abstract}
${ }^{2}$ The Joint Graduate School of Energy and Environment, King Mongkut's University of Technology, Bangkok, Thailand

${ }^{3}$ Civil Engineering Department, COMSATS University Islamabad, Wah Campus, Wah Cantt, Pakistan, e-mail: tariqshah457@gmail.com
\end{abstract}

Received Date: October 2, 2020; Revised Date: February 5, 2021; Acceptance Date: April 8, 2021

\begin{abstract}
Cambodia and Laos are two countries located in Southeast Asia. During the COVID-19 pandemic outbreak, people in these two countries are encouraged to work to sustain economic activities and therefore travel normally. A sound understanding of travel behavior in these two countries, however, has remained unknown during the global pandemic. This study explored the travel behavior of commuters for key destinations (i.e., workplace, market, and hospital) during the COVID-19 pandemic in Cambodia and Laos. The study used the primary dataset of 217 observations collected online from 29 March through 4 April 2020 using the simple random sampling technique. The multinomial logit model (MNL) was used for statistical data analysis. The results showed that males were more likely than females to go to work by motorcycle, followed by car and walking/cycling. Private/industry employees and state officials/public servants were likely to go to work, but academics/researchers, the self-employed, and the jobless/students were inclined not to travel. People living in cities had a higher preference to travel to work by car and motorcycle. People living in Laos were least likely to travel to the three key destinations by motorcycle and most likely to travel to the workplace and market by car, as compared to people living in Cambodia. Overall, the COVID-19 pandemic leads to changes in people's lifestyles as well as travel behavior. People preferred modes of private transport to public transport to obey social distancing, thereby avoiding getting infected with the virus. These solutions can simultaneously minimize the economic loss and slow down the spread of the COVID-19 disease.
\end{abstract}

Keywords: Cambodia, Choice modeling, Laos, SARS-CoV-2, Travel patterns

\section{Introduction}

COVID-19 is a new infectious disease unknown before the outbreak began in Wuhan, China, in December 2019 \{Formatting Citation\}. This disease causes respiratory infections ranging from the common cold to more severe diseases such as Middle East Respiratory Syndrome 
and Severe Acute Respiratory Syndrome [1]. As of 25 April 2020, this epidemic sweeps across 213 countries and territories with a total of 2,631,839 confirmed cases and 182,100 confirmed death toll globally [2]. All the countries in Southeast Asia report the confirmed COVID-19 cases. The Association of Southeast Asian Nations (ASEAN) is a regional intergovernmental organization comprising ten countries in Southeast Asia such as Indonesia, Thailand, Singapore, Malaysia, Philippines, Vietnam, Brunei, Cambodia, Laos, and Myanmar (Burma). As of 24 April 2020, Singapore reported the most confirmed COVID-19 cases with a figure of 11,178 in the region, followed by Indonesia, Philippines, Malaysia, Thailand, and the others. On the same date, Laos and Cambodian governments can curb the COVID-19 disease with a report of the total numbers of 19 and 122 confirmed cases, respectively. The map of Cambodia and Laos is shown in Figure 1. These two countries are located between Vietnam and Thailand in Southeast Asia.

The COVID-19 disease significantly spreads from a person with the disease to another one when the person with COVID-19 expels small droplets through coughs, sneezes, or speaks and, another person breath in the droplets [3]. Also, the droplets can land on objects and surfaces (e.g., tables, doorknobs, and handrails), and people can be infected by touching their eyes, nose, or mouth after touching these objects or surfaces [3]. Besides entertainment venues and schools, public transport modes are also the high-risk venues of spreading the COVID-19 pandemic. Understanding the determinants of travel mode choice for key destinations (e.g., workplaces, markets, hospitals) in countries with very few COVID-19 confirmed cases are informative for other countries to curb and slow down the spread of the disease and keep equity in passenger mobility. The Cambodian government encourages people to work normally to boost national and household economic activities during the ripple effect, other than people working at academic institutions and some entertainment venues (i.e., karaoke, bars, and movie theaters). Also, the government simultaneously fights against the epidemic. Similarly, the Lao government motivates people to work normally, except the people working at the venues of high risks. Correspondingly, people still travel normally to key destinations. However, the governments of these two countries issued travel restrictions intermittently to control the spreading of the COVID-19. People who stay at home during the COVID-19 outbreak experience more stress than happiness [4], probably due to limited physical activities.

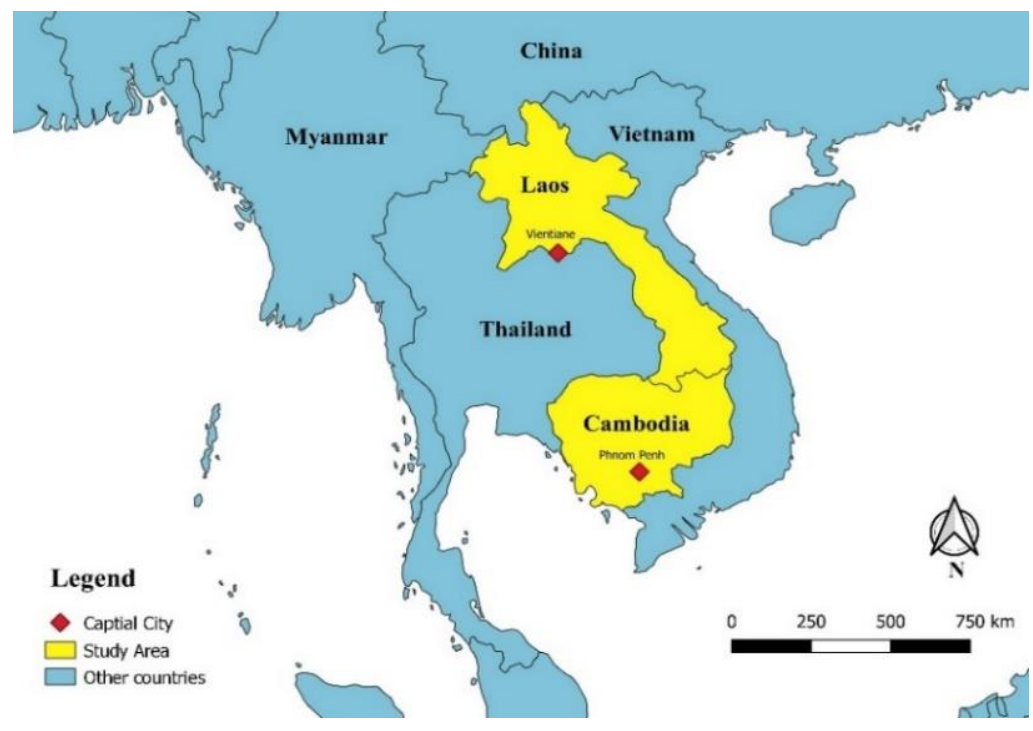

Figure 1. The map of Cambodia and Laos (adopted from Google Maps [5]) 
The reports of COVID-19 cases in terms of time is illustrated in Figure 2 for Laos and Figure 3 for Cambodia. Most of the confirmed cases are imported, not the infection in the community. The governmental strategies and policies of these two countries are well performed to control and fight against the COVID-19 spread. The timeline of policies and strategies regarding travel restrictions for these two countries is shown as follows:

\section{- For Laos}

○ 13 March, 2020: Some border checkpoints were temporarily closed by the provincial governors [6].

○ 24 March, 2020: The government reported the first two confirmed COVID-19 cases in Vientiane, and Laos become the last country that reported the confirmed COVID19 cases in the region [7].

○ 29 March, 2020: The country was in lockdown starting from 30 March, all the inland borders were temporarily closed, and the last flights departed from Luang Prabang and Vientiane occurred on 01 April 2020 [8].

○ 18 May, 2020: Some restrictions were extricated, and only Lao people were allowed to travel domestically and in their provinces [9].

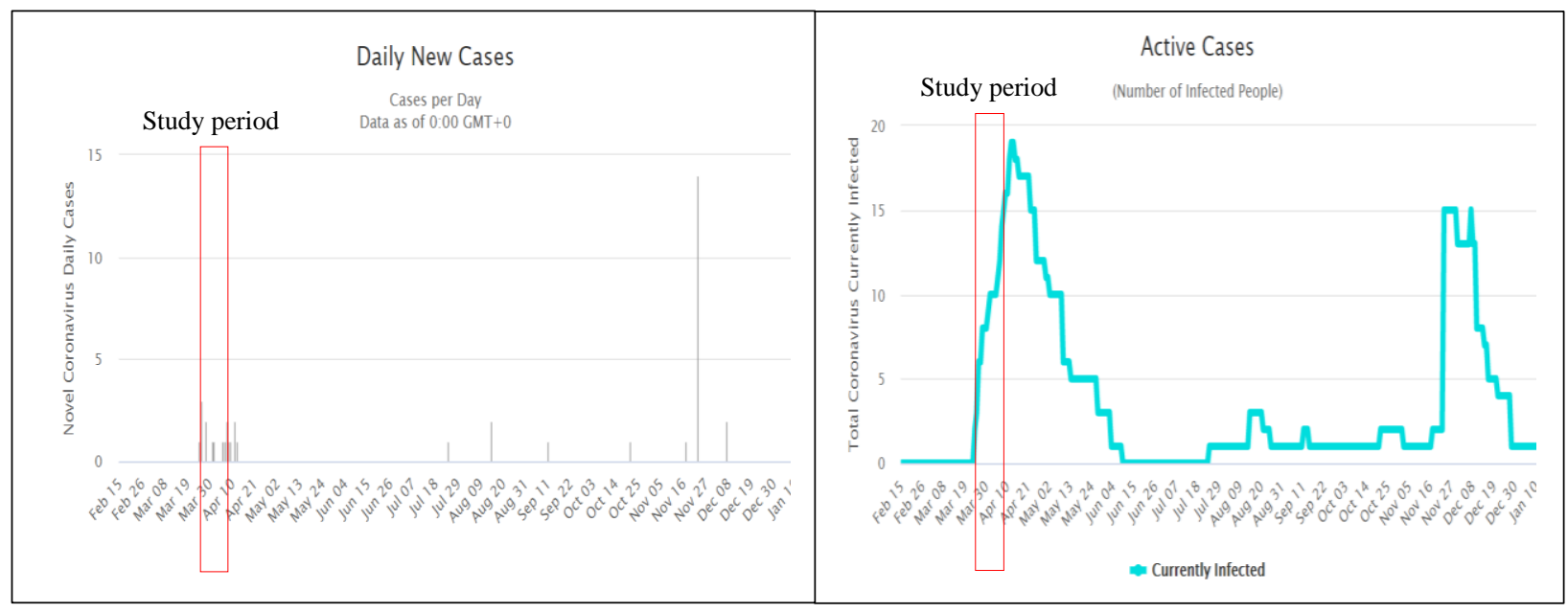

Figure 2. Daily New Cases and Active Cases in Laos in 2020 [10]

\section{- For Cambodia}

○ 7 March 2020: The first Cambodian man, aged 38 years old, was diagnosed with COVID-19 in Siem Reap. Also, the government decided to close all schools and canceled the upcoming National New Year festival in the city [11].

○ 17 March, 2020: The government directed the expanded closure to karaoke clubs, cinemas, and concerts [12].

- 18 March, 2020: The government established a national committee to fight against the COVID-19 disease, and the committee is responsible to develop the national policy and strategy and control the impact of the virus on politics, economy, and society at the national and international levels [13].

○ 28 March, 2020: The government mandated travel restrictions and implemented from 30 March 2020. Foreigners had to obtain a visa and got a medical certificate issued no longer than 72 hours before arrival time [14]. 
○ 8 April, 2020: Khmer New Year festival scheduled on 13-16 April 2020 was canceled without holiday for all employees and officials [15]. However, the government promised to provide each laid-off worker US\$ 70 a month [16]. Employees who went on holidays had to take quarantine for two weeks without getting paid after they returned to work [17].

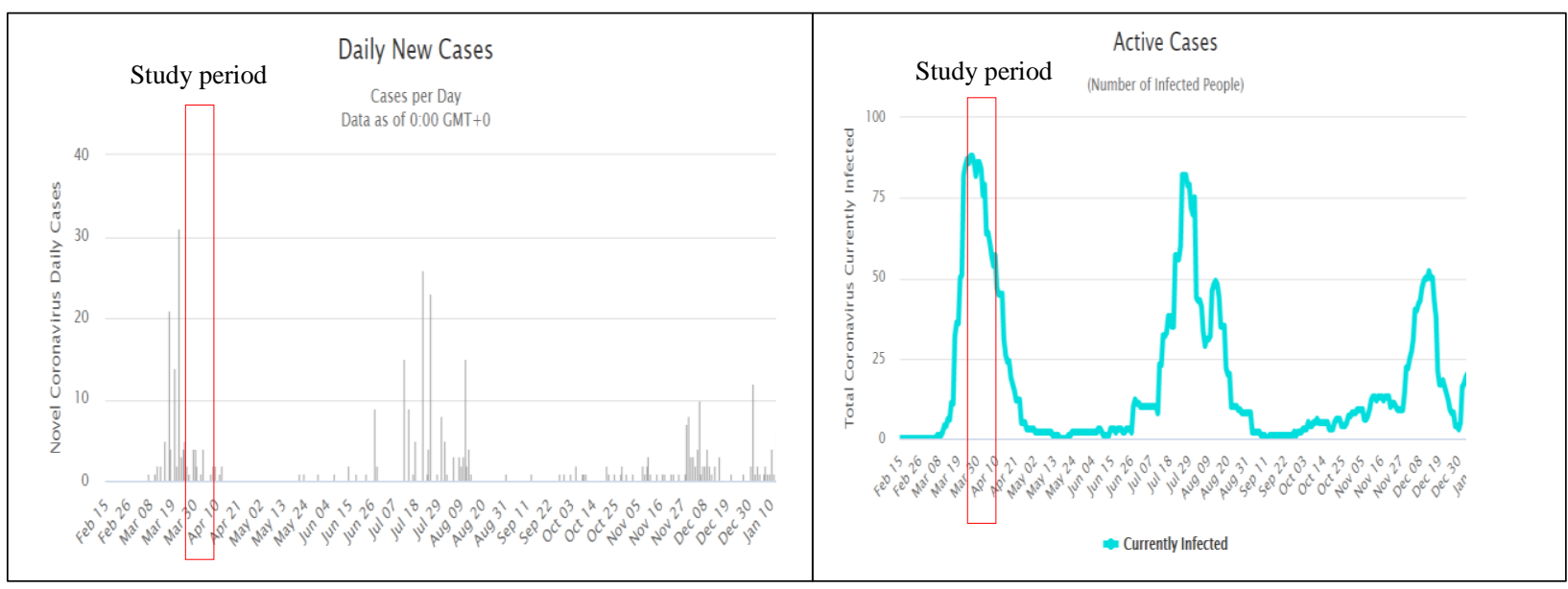

Figure 3. Daily New Cases and Active Cases in Cambodia in 2020 [18]

During the COVID-19 pandemic, people are more concerned about their health, specifically traveling in crowded public transport modes. They prefer to use private modes instead of public transport during the COVID-19 outbreak. However, the factors that incline them to chose transport mode have remained unknown during the global pandemic. This study explored the potential determinants of travel mode choice for the three key destinations (i.e. workplace, market, and hospital) for the two ASEAN countries, i.e., Cambodia and Laos. The study used the primary dataset of 217 observations collected online from 29 March through 4 April 2020 based on the simple random sampling technique, and the Google Form was used as a survey instrument. The multinomial logistic regression (MNL) was applied to develop three different travel mode choice models for the different key destinations. From the transport policy perspective, these different models help us to better understand the different impacts of various explanatory variables on travel mode choice by trip purpose, i.e., workplace, market, and hospital. This is the novel case study of travel patterns for the key destinations in ASEAN countries with the least confirmed COVID-19 cases during the global pandemic. The primary motivation of this research is that a thorough understanding of travel behavior for the key destinations (i.e., workplace, market, and hospital) from ASEAN countries with the least COVID-19 confirmed cases are informative for other ASEAN countries to sustain equity in on-road passenger mobility with a minimum economic loss while the COVID-19 is being well controlled. However, this study has some limitations in terms of small data sample size, and only literate people who had internet access participated in filling out the questionnaire form. Furthermore, the sample data are the self-reporting data that cannot avoid a lack of honest, accurate, and bias-free reporting.

The remainder of this article is organized as follows. Section 2 describes the data source and methodology, Section 3 presents the model estimation results and discussion of lessons learned from Cambodia and Laos to curb the COVID-19 disease outbreak successfully, and Section 4 concludes the findings and provides directions for future research to address various issues triggered by the COVID-19 outbreak in ASEAN countries as well the whole region. 


\section{Materials and Methods}

\section{Data Source and Descriptive Statistics}

The web-based survey approach was carried out to collect the sample from 29 March through 4 April 2020 using the Google Form as a survey tool. The link was posted on Facebook social media, and the survey form was written in three different languages, i.e., English, Khmer, and Laotian. All the respondents must be at least 18 years old and live in Cambodia and Laos. There were only 227 respondents volunteered to fill out the survey form. The questionnaire forms without complete answers were deliberately removed to avoid data inconsistency, and there exist only 217 samples after data cleaning (i.e., 128 and 89 respondents from Cambodia and Laos, respectively) for the statistical data analysis. This data sampling was based on the simple random sampling technique. According to the Cochran formula, the sample size of 217 provides a confidence level of $95 \%$ with a margin of error of $6.65 \%$ if the sample estimate of proportion in the population, $p$, is assumed to be 0.5 (the proportion that provides the highest standard error) [19]. The sample size can be approximate using the equation below [19]:

$$
\text { Margin of error }=Z \text { score of confidence level } \times \sqrt{\frac{p(1-p)}{\text { sample size }}}
$$

In our case study, the population size is unlimited. The proportion, $p$, of 0.5 provides the greatest margin of error, and the smaller margin of error is preferable. The sample with more than 30 observations is considered a large size sample [20]. A sample of 30-60 observations is probably enough for hypothesis testing, and the sample size for the conjoint analysis generally ranges from 150 to 1,200 observations [19].

The descriptive statistics of the variables in terms of frequency and percentage are shown in Table 1. There are three output variables of travel mode choice from home to key destinations during the COVID-19 disease outbreak, i.e., workplace, market, and hospital. The travel modes are classified into five categories, such as bus/van, car, motorcycle, walking/cycling, and no travel (stay at home). Of all the respondents, 35.9\%, 21.2\%, and $67.3 \%$ do not go to the workplace, market, and hospital during the COVID-19 pandemic. Among commuters, the motorcycle is the dominant mode for the three key destinations, followed by car, walking/cycling, and bus/van. The percentage shares of the bus/van are $2.3 \%$ for home to work and less than $1 \%$ for home to market and home to hospital. The small percentage share of the public transport mode contributes to slow down the COVID-19 pandemic due to the performance of social distancing during traveling. This transport mode choice decision in Cambodia is mainly influenced by the only public bus availability in the capital city and the travel restrictions caused by the COVID-19 outbreak during the data sampling. The public bus was temporarily suspended since 27 March 2020 to prevent the spread of COVID-19 [21]. Unlike during the pre-COVID-19 pandemic, highschool students were more likely to use the public bus more often than other passengers in the capital city of Cambodia [22]. In Laos, public buses are mostly used for intercity traveling with long distances [34]. The choices of "No, I do not go to the market" and "No, I do not go to the hospital" were made by the respondents without constraint because there were no travel restrictions for these two key destinations in Cambodia and Laos before and during the sample data collection. However, the choice of "No, I do not go to work" made by 
academics, students, and researchers was influenced by the regulations of the research and educational institutions. They were asked to work/study online at home, unlike the employees of private companies and factories and the state officials.

Table 1. Descriptive Statistics of the Data Sample - Counts and Proportion

\begin{tabular}{|c|c|c|c|c|}
\hline $\begin{array}{l}\text { Output } \\
\text { Variable }\end{array}$ & Description & Categories & Counts & Proportion \\
\hline Workplace & $\begin{array}{l}\text { Travel mode } \\
\text { choice from home } \\
\text { to work }\end{array}$ & $\begin{array}{l}\text { Bus/van } \\
\text { Car } \\
\text { Motorcycle } \\
\text { Walking/cycling } \\
\text { No, I do not go to work }\end{array}$ & $\begin{array}{c}5 \\
47 \\
72 \\
15 \\
78\end{array}$ & $\begin{array}{c}2.3 \% \\
21.7 \% \\
33.2 \% \\
6.9 \% \\
35.9 \%\end{array}$ \\
\hline Market & $\begin{array}{l}\text { Travel mode } \\
\text { choice from home } \\
\text { to the market }\end{array}$ & $\begin{array}{l}\text { Bus/van } \\
\text { Car } \\
\text { Motorcycle } \\
\text { Walking/cycling } \\
\text { No, I do not go to the market }\end{array}$ & $\begin{array}{c}1 \\
59 \\
92 \\
19 \\
46\end{array}$ & $\begin{array}{c}0.5 \% \\
27.2 \% \\
42.4 \% \\
8.8 \% \\
21.2 \% \\
\end{array}$ \\
\hline Hospital & $\begin{array}{l}\text { Travel mode } \\
\text { choice from home } \\
\text { to the hospital }\end{array}$ & $\begin{array}{l}\text { Bus/van } \\
\text { Car } \\
\text { Motorcycle } \\
\text { Walking/cycling } \\
\text { No, I do not go to the hospital }\end{array}$ & $\begin{array}{c}2 \\
29 \\
36 \\
4 \\
146\end{array}$ & $\begin{array}{c}0.9 \% \\
13.4 \% \\
16.6 \% \\
1.8 \% \\
67.3 \%\end{array}$ \\
\hline $\begin{array}{l}\text { Input } \\
\text { Variable }\end{array}$ & Description & Variable Categories & Counts & Proportion \\
\hline Socioeconomi & Characteristics & & & \\
\hline Gender & Gender & $\begin{array}{l}\text { Female } \\
\text { Male }\end{array}$ & $\begin{array}{c}97 \\
120\end{array}$ & $\begin{array}{l}44.7 \% \\
55.3 \%\end{array}$ \\
\hline Education & $\begin{array}{l}\text { Educational } \\
\text { degree }\end{array}$ & $\begin{array}{l}\text { Bachelor's degree } \\
\text { Master's/doctoral degree }\end{array}$ & $\begin{array}{c}121 \\
63\end{array}$ & $\begin{array}{l}55.8 \% \\
29.0 \%\end{array}$ \\
\hline Occupation & Occupation type & $\begin{array}{l}\text { Academic/researcher } \\
\text { Company/industry employee } \\
\text { State official/public servant } \\
\text { Self-employed person } \\
\text { The jobless/student }\end{array}$ & $\begin{array}{l}17 \\
70 \\
44 \\
18 \\
68\end{array}$ & $\begin{array}{c}7.8 \% \\
32.3 \% \\
20.3 \% \\
8.3 \% \\
31.3 \%\end{array}$ \\
\hline $\begin{array}{l}\text { Family } \\
\text { status }\end{array}$ & $\begin{array}{l}\text { Status of the } \\
\text { respondent }\end{array}$ & $\begin{array}{l}\text { Child } \\
\text { Parent }\end{array}$ & $\begin{array}{c}156 \\
61\end{array}$ & $\begin{array}{l}71.9 \% \\
28.1 \%\end{array}$ \\
\hline Family size & $\begin{array}{l}\text { Number of family } \\
\text { members }\end{array}$ & $\begin{array}{l}3 \text { people and less than } \\
4 \text { people } \\
5 \text { people } \\
6 \text { people and more }\end{array}$ & $\begin{array}{l}33 \\
54 \\
59 \\
71\end{array}$ & $\begin{array}{l}15.2 \% \\
24.9 \% \\
27.2 \% \\
32.7 \%\end{array}$ \\
\hline Income & $\begin{array}{l}\text { Household } \\
\text { income per month }\end{array}$ & $\begin{array}{l}\text { Less than } 1,000 \text { US\$ } \\
1,000 \text { to } 2,000 \text { US\$ } \\
\text { More than } 2,000 \text { US\$ }\end{array}$ & $\begin{array}{c}119 \\
68 \\
30\end{array}$ & $\begin{array}{l}54.8 \% \\
31.3 \% \\
13.8 \%\end{array}$ \\
\hline
\end{tabular}




\begin{tabular}{|c|c|c|c|c|}
\hline $\begin{array}{l}\text { Input } \\
\text { Variable }\end{array}$ & Description & Variable categories & Counts & Proportion \\
\hline \multicolumn{5}{|c|}{ Home location-related variable } \\
\hline \multirow[t]{2}{*}{ Country } & \multirow{2}{*}{$\begin{array}{l}\text { The country a } \\
\text { respondent is } \\
\text { living }\end{array}$} & Cambodia & 128 & $59.0 \%$ \\
\hline & & Laos & 89 & $41.0 \%$ \\
\hline \multirow[t]{2}{*}{ Resident } & \multirow[t]{2}{*}{$\begin{array}{l}\text { Home location } \\
\text { type }\end{array}$} & City & 111 & $51.2 \%$ \\
\hline & & Town/rural area & 106 & $48.8 \%$ \\
\hline \multirow{3}{*}{$\begin{array}{l}\text { Distance to } \\
\text { workplace }\end{array}$} & \multirow{3}{*}{$\begin{array}{l}\text { Distance from } \\
\text { home to the } \\
\text { workplace }\end{array}$} & Less than $5 \mathrm{~km}$ & 98 & $45.2 \%$ \\
\hline & & About 5 to $10 \mathrm{~km}$ & 68 & $31.3 \%$ \\
\hline & & More than $10 \mathrm{~km}$ & 51 & $23.5 \%$ \\
\hline \multirow{3}{*}{$\begin{array}{l}\text { Distance to } \\
\text { market }\end{array}$} & \multirow{3}{*}{$\begin{array}{l}\text { Distance from } \\
\text { home to the } \\
\text { market }\end{array}$} & Less than $5 \mathrm{~km}$ & 172 & $79.3 \%$ \\
\hline & & About 5 to $10 \mathrm{~km}$ & 34 & $15.7 \%$ \\
\hline & & More than $10 \mathrm{~km}$ & 11 & $5.1 \%$ \\
\hline \multirow{3}{*}{$\begin{array}{l}\text { Distance to } \\
\text { hospital }\end{array}$} & \multirow{3}{*}{$\begin{array}{l}\text { Distance from } \\
\text { home to the } \\
\text { hospital }\end{array}$} & Less than $5 \mathrm{~km}$ & 105 & $48.4 \%$ \\
\hline & & About 5 to $10 \mathrm{~km}$ & 77 & $35.5 \%$ \\
\hline & & More than $10 \mathrm{~km}$ & 35 & $16.1 \%$ \\
\hline \multicolumn{3}{|l|}{ Total } & 217 & $100.0 \%$ \\
\hline
\end{tabular}

\section{Multinomial Logistic Regression (MNL)}

Travel mode choice is a categorical variable, and a discrete choice model can be applied to statistically analyze the sample data. Two discrete choice models are widely applied, i.e., the multinomial logistic regression (MNL) and the multinomial probit regression (MNP). The MNP cannot be used to model our data sample because the sample size is too small (i.e., only 217 samples). Furthermore, there are five categories for the travel mode choice and eleven input variables, and all the input variables are the categorical variables. Specifically, the MNP is applied to capture the correlations of unobserved terms over time and alternatives, and our data sample is not a kind of temporal data. The MNL is mostly used to model the disaggregated data, thanks to its simplicity in the mathematical framework and flexibility for any data type and sample size.

Therefore, the MNL was applied for our study. According to the principle of the discrete choice model, the alternatives of the choice set must be mutually exclusive (i.e., choice makers can choose only one alternative from the choice set), exhaustive (i.e., all possible alternatives are included in the choice set), and finite (i.e., the number of alternatives is countable) [23]. In our models, the choice set is made up of five alternatives, including bus/van, car, motorcycle, walking/cycling, and no travel. The probability of an alternative chosen by a choice maker is written as follows [23]:

$$
P_{n, i}=\frac{e^{\beta^{\prime} x_{n, i}}}{\sum_{j} e^{\beta^{\prime} x_{n, j}}}
$$

where the indices $n$ and $i$ are the choice maker and alternative, respectively ( $i \in I$ and $I=$ $1 \ldots J ; J$ is the finite number of a choice set). $x$ is a column vector of the input variables (including a constant, socioeconomic variables, and home location-related characteristics) affecting the utility, and $\beta$ is the corresponding parameter estimate (column) vector. 
The maximum likelihood function is typically used to estimate the parameters [23]:

$$
\operatorname{LL}(\beta)=\sum_{n=1}^{N} \sum_{i} y_{n, i} \ln \left(P_{n, i}\right)
$$

where $y_{n, i}\left[y_{n, i}=1\right]$ is the dummy variable of an alternative, $i$, chosen by an individual, $n$. $\mathrm{LL}$ is the log-likelihood function.

The package "mlogit" of $\mathrm{R}$ programming language was used to estimate the parameters [24], and a Core i3 laptop with a 4 GB ram was employed.

\section{Dummy Coding}

As mentioned earlier, all the input variables are categorical; therefore, the attribute levels of all the input variables are arranged as the dummy coding. The dummy coding can capture the non-linear effects in the levels of attributes, and the number of new variables created is equivalent to the number of attribute levels being coded, minus one [25]. In our study, the first attribute level of each input variable is used as the reference category. For example, the monthly household income has three categories, i.e., less than 1,000 US\$, from 1,000 to 2,000 US\$, and more than 2,000 US\$ (see Table 2).

There are two dummy variables (i.e., income 1 and income 2), and the category of less than 1,000 US\$ is used as the reference category. If a respondent belongs to the category of less than 1,000 US\$, the dummy coding is 0 for income 1 and income 2 . If a respondent belongs to the category of 1,000 to 2,000 US\$, the dummy coding is 1 for income 1 and 0 for income 2. If a respondent belongs to the category of more than 2,000 US\$, the dummy coding is 0 for income 1 and 1 for income 2 . This dummy coding approach is applied to the other categorical input variables.

\section{Table 2. Dummy Coding}

\begin{tabular}{lrr}
\hline Monthly Household Income & Income 1 & Income 2 \\
Less than 1,000 US\$ & 0 & 0 \\
1,000 to 2,000 US\$ & 1 & 0 \\
More than 2,000 US\$ & 0 & 1 \\
\hline
\end{tabular}

\section{Results and Discussion}

This section is made up of two subsections, including the model estimation results and the travel behavior of people in Cambodia and Laos during the COVID-19 outbreak.

\section{Model Estimation Results}

Regarding Table 1, the frequencies of bus/van mode for all the three destinations are too small, i.e., 5 counts for the workplace, 1 count for the market, and 2 counts for the hospital. Correspondingly, we cannot include the bus/van alternative in the choice set due to model violation. The people residing in Cambodia and Laos typically do not travel by bus/van during the COVID-19 disease outbreak, and this is consistent with very few confirmed COVID-19 cases, i.e., only 122 cases in Cambodia and 19 cases in Laos in total, as of 23 April 2020 [26]. Therefore, there are four alternatives in the choice set to develop travel mode choice models for the three key destinations in our study. 
The travel mode choice models were developed by adding one variable after another to evaluate the potential variables and control the multicollinearity. At the same time, we also checked the correlation among the statistically significant variable (at the 0.1 significance level) using the Pearson's Product-Moment Correlation approach. If the correlation coefficient is higher than 0.5 , one significant variable is removed.

The other significant variable providing a higher log-likelihood value remains in the discrete choice models. We have four alternatives, and therefore, the degree of freedom, $k$, of each variable is equal to 3 . Each variable added to the model increases $k$ by 3 . The critical chi-square, $\chi^{2}$, at the 0.1 significance level for $k=3$ is 6.251 .

The log-likelihood value and likelihood ratio test are presented in Table 3. Only the added variables with the likelihood ratio indices higher than the critical $\chi^{2}$ of 6.251 are remained in the travel mode choice models (i.e., workplace, market, and hospital).

As mentioned already, the first attribute level of each input variable is used as the reference category. All the input variables listed in Table 3 are the potential determinants of travel mode choice for the three key destinations during the COVID-19 pandemic outbreak. The correlation coefficients among the significant variables are shown in Table 4.

The strongest correlation of -0.446 was found between the jobless/student and company/industry employee, followed by the correlation of -0.341 between the state official/public servant and the jobless/student variables. The other correlation coefficients are around 0.3 and less.

All the correlation coefficients are less than 0.5 , and therefore, the multicollinearity problem is ignorable for the three developed models. It always assumes collinearity to be relatively low for the discrete choice model because it is difficult to differentiate the impact of each input variable on each category of the output variable [27].

Table 3. Likelihood Ratio Index Based on the Forward Selection Method

\begin{tabular}{|c|c|c|c|c|c|c|c|c|c|}
\hline \multirow[b]{2}{*}{ Variable } & \multicolumn{3}{|c|}{ Workplace } & \multicolumn{3}{|c|}{ Market } & \multicolumn{3}{|c|}{ Hospital } \\
\hline & $\mathrm{k}$ & Log-likelihood & $\begin{array}{l}\text { Likelihood } \\
\text { ratio index }\end{array}$ & $\mathrm{k}$ & Log-likelihood & $\begin{array}{l}\text { Likelihood } \\
\text { ratio index }\end{array}$ & $\mathrm{k}$ & Log-likelihood & $\begin{array}{l}\text { Likelihood } \\
\text { ratio index }\end{array}$ \\
\hline Intercept & 3 & -266.28 & - & 3 & -272.42 & - & 3 & -194.88 & - \\
\hline Gender & 6 & -259.32 & 13.92 & 6 & -267.09 & 10.66 & 6 & -191.16 & 7.44 \\
\hline Master/Ph.D. & 9 & -256.11 & 6.42 & 9 & -262.28 & 9.62 & - & - & - \\
\hline Company/industry employee & 12 & -250.33 & 11.56 & 12 & -257.58 & 9.4 & - & - & - \\
\hline State official/public servant & 15 & -242.66 & 15.34 & 15 & -254.13 & 6.9 & - & - & - \\
\hline Self-employed person & 18 & -234.65 & 16.02 & 18 & -241.02 & 26.22 & - & - & - \\
\hline No job/student & 21 & -230.2 & 8.9 & - & - & - & 9 & -181.3 & 19.72 \\
\hline $1,000-2,000$ USS & 24 & -226.9 & 6.6 & - & - & - & & & \\
\hline More than 2,000 US\$ & 27 & -212.45 & 28.9 & 21 & -226.97 & 28.1 & 12 & -172.95 & 16.7 \\
\hline Laos & 30 & -199.27 & 26.36 & 24 & -217.57 & 18.8 & 15 & -165.82 & 14.26 \\
\hline Town/rural area & 33 & -192.91 & 12.72 & - & - & - & - & - & - \\
\hline
\end{tabular}


Table 4. Correlation Coefficients among the Output Variables and Significant Input Variables

\begin{tabular}{|c|c|c|c|c|c|c|c|c|c|c|c|c|c|}
\hline & 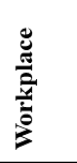 & 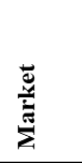 & 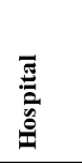 & 它 & $\frac{O}{3}$ & 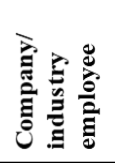 & 莺 & 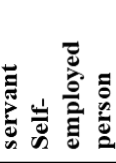 & 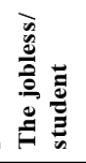 & 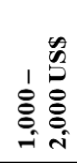 & 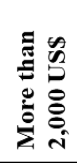 & $\stackrel{\mathscr{\Xi}}{\Xi}$ & : \\
\hline Workplace & 1.000 & & & & & & & & & & & & \\
\hline Market & 0.243 & 1.000 & & & & & & & & & & & \\
\hline Hospital & 0.327 & 0.258 & 1.000 & & & & & & & & & & \\
\hline Gender & -0.197 & -0.043 & -0.087 & 1.000 & & & & & & & & & \\
\hline Master/Ph.D. & -0.075 & 0.018 & -0.077 & -0.058 & 1.000 & & & & & & & & \\
\hline Company/industry employee & -0.206 & -0.029 & -0.037 & 0.045 & -0.137 & 1.000 & & & & & & & \\
\hline State official/ public servant & -0.061 & -0.024 & -0.111 & -0.123 & 0.384 & -0.348 & 1.000 & & & & & & \\
\hline Self-employed person & 0.096 & 0.008 & 0.024 & -0.133 & -0.045 & -0.208 & -0.152 & 1.000 & & & & & \\
\hline The jobless/ student & 0.188 & 0.082 & 0.111 & 0.128 & -0.257 & -0.466 & -0.341 & -0.203 & 1.000 & & & & \\
\hline $1,000-2,000 \mathrm{USS}$ & -0.052 & 0.099 & -0.074 & 0.008 & 0.071 & 0.001 & 0.030 & -0.059 & -0.071 & 1.000 & & & \\
\hline More than 2,000 USS & 0.178 & 0.110 & 0.104 & -0.150 & 0.156 & 0.038 & 0.030 & 0.218 & -0.213 & -0.271 & 1.000 & & \\
\hline Laos & 0.307 & 0.160 & 0.243 & -0.230 & 0.107 & -0.014 & 0.162 & 0.157 & -0.180 & -0.079 & 0.236 & 1.000 & \\
\hline Town/rural & 0.323 & 0.124 & 0.030 & -0.197 & 0.005 & -0.142 & 0.080 & 0.074 & 0.035 & -0.024 & 0.089 & 0.328 & 1.000 \\
\hline
\end{tabular}

The estimation results of the streamlined model are presented in Table 5. The first and second columns refer to the input variables and transport modes, respectively. The last three columns are the parameter estimates of the streamlined models of the workplace, market, and hospital destinations. The intercept coefficients are included to capture the average unobserved effect, and they have no interpretable meaning [23].

For the gender variable, males were more likely than females to go to work by motorcycle, followed by car and active mode (i.e., walking/cycling). A similar study in Metro Manila, Philippines, in the pre-COVID-19 outbreak indicated that males were more likely to go to work by motorcycle than females [28]. This also implied that females had a higher likelihood to stay at home than to work during the COVID-19 outbreak. Males were most likely to go to the market by walking/cycling, followed by motorcycle and car. Females were more prone than males to go to market by car during the COVID-19 outbreak. Males had a higher preference than females to travel by motorcycle and car to the hospital, and males were likely to go to the hospital during the COVID-19 outbreak rather than to stay at home.

For the education level variable, the bachelor category had no impact on the travel mode choice for the three destinations, while the Master/Ph.D. category was found a relationship with the travel mode choice for the workplace and market destinations. Those with master/Ph.D. degrees were more likely to go to work and market than to stay at home. Highly educated people with master/Ph.D. degrees were most likely to travel by walking/cycling, followed by car and motorcycle because those people might have good 
jobs with high income. Therefore, they might afford to own houses near their workplaces and the markets and purchase cars and motorcycles. Similarly, households with the presence of household heads with bachelor's degrees and higher were likely to own cars [29][30]. Respondents with high school degrees and lower were likely to stay at home.

For the occupation variable, private/industry employees and state officials/public servants went to work rather than stayed at home, while academics/researchers, self-employed persons, and no job/students were likely to stay at home and probably to be active with their job and study at home. The jobless/students were the least likely to go to the hospital.

For the income variable, people belonging to families with a household income of $1,000-2,000$ US $\$$ were more likely to go to work by car, followed by walking/cycling and motorcycle, while people with a household income of more than 2,000 US\$ were more inclined to go to the workplace, market, and hospital by car than motorcycle.

For the country variable, people living in Laos were least likely to travel to the workplace, market, and hospital by motorcycle and most likely to travel to the workplace and market by car, as compared to people living in Cambodia. People residing in Cambodia were most likely to travel by motorcycle to the workplace, market, and hospital.

For the resident location variable, people living in a city were more likely than people living in a town/rural area to travel to work by car, followed by motorcycle. Furthermore, it was found no existent relationship of the travel distance with travel mode choice for the market and hospital destinations at the 0.1 significance level. This, however, might not necessarily imply that the distance had no impact on the travel mode choice among the commuters' mindset. If the travel distance interval is rearranged in shorter, or the continuous variable of travel distance is used to replace the categorical variable, the travel mode choice for the market and hospital destinations might be somewhat influenced by the travel distance. Those living farther than $10 \mathrm{~km}$ had a higher likelihood to stay at home than to go to work.

Table 5. The Streamlined Model Estimation Results

\begin{tabular}{llccc}
\hline Variable & Travel mode & \multicolumn{2}{l}{ Coefficient (std. error) } & \\
\cline { 2 - 5 } & & Workplace & Market & Hospital \\
\hline Intercept & Motorcycle & $0.699(0.86)$ & $0.992(0.41)^{*}$ & $-0.737(0.37)^{*}$ \\
& Car & $-20.362(5421.85)$ & $-1.297(0.56)^{*}$ & $-1.151(0.41)^{* *}$ \\
& Walking/cycling & $-21.251(5076.06)$ & $-0.578(0.62)$ & $-68.593(8415)$ \\
\cline { 2 - 5 } Gender & & & \\
Female (ref.) & & & & \\
Male & Motorcycle & $1.031(0.42)^{*}$ & $0.237(0.39)$ & $0.352(0.42)$ \\
& Car & $0.53(0.46)$ & $-0.167(0.45)$ & $0.087(0.43)$ \\
Education & Walking/cycling & $0.374(0.66)$ & $0.505(0.61)$ & $32.846(5333)$ \\
\cline { 2 - 5 } High school or lower & & & \\
(ref.) & & & & \\
Master/Ph.D. & Motorcycle & $0.443(0.53)$ & $0.159(0.49)$ & - \\
& Car & $0.523(0.51)$ & $0.732(0.52)$ & - \\
& Walking/cycling & $1.35(0.76)$. & $1.191(0.69)$. & - \\
\cline { 2 - 5 } & & & \\
\end{tabular}




\begin{tabular}{|c|c|c|c|c|}
\hline \multirow[t]{2}{*}{ Variable } & \multirow[t]{2}{*}{ Travel mode } & \multicolumn{3}{|l|}{$\begin{array}{l}\text { Coefficient (std. } \\
\text { error) }\end{array}$} \\
\hline & & Workplace & Market & Hospital \\
\hline \multicolumn{5}{|l|}{$\begin{array}{l}\text { Academic/researcher } \\
\text { (ref.) }\end{array}$} \\
\hline \multirow{3}{*}{$\begin{array}{l}\text { Private/industry } \\
\text { employee }\end{array}$} & Motorcycle & $0.703(0.77)$ & $-0.002(0.42)$ & - \\
\hline & Car & $20.124(5421.85)$ & $0.49(0.55)$ & - \\
\hline & Walking/cycling & $18.603(5076)$ & $-2.424(1.10)^{*}$ & - \\
\hline \multirow{3}{*}{$\begin{array}{l}\text { State official/public } \\
\text { servant }\end{array}$} & Motorcycle & $0.537(0.82)$ & $0.128(0.60)$ & - \\
\hline & Car & $20.299(5421.85)$ & $1.326(0.66)^{*}$ & - \\
\hline & Walking/cycling & $17.532(5076.06)$ & $-1.213(0.96)$ & - \\
\hline \multirow{3}{*}{$\begin{array}{l}\text { Self-employed } \\
\text { person }\end{array}$} & Motorcycle & $-0.569(1.14)$ & $0.24(1.28)$ & - \\
\hline & Car & $19.926(5421.85)$ & $3.02(1.14)^{* *}$ & - \\
\hline & Walking/cycling & $18.132(5076.06)$ & $1.547(1.31)$ & - \\
\hline \multirow[t]{3}{*}{ The jobless/student } & Motorcycle & $-0.86(0.77)$ & - & $-0.788(0.43)$ \\
\hline & Car & $17.699(5421.85)$ & - & $-2.017(0.77)^{* *}$ \\
\hline & Walking/cycling & $19.237(5076.06)$ & - & $33.748(4762.7)$ \\
\hline \multicolumn{5}{|c|}{ Income } \\
\hline \multicolumn{5}{|c|}{ Less than 1,000 US\$ (ref.) } \\
\hline \multirow[t]{3}{*}{$1,000-2,000 \mathrm{US} \$$} & Motorcycle & $-0.241(0.45)$ & - & - \\
\hline & Car & $1.165(0.52)^{*}$ & - & - \\
\hline & Walking/cycling & $1.628(0.73)^{*}$ & - & - \\
\hline \multirow[t]{3}{*}{ More than 2,000 US\$ } & Motorcycle & $-19.304(3184.37)$ & $-2.557(1.12)^{*}$ & $-20.29(11599)$ \\
\hline & Car & $0.762(0.58)$ & $1.048(0.57)$ & $0.335(0.52)$ \\
\hline & Walking/cycling & $0.495(1.10)$ & $-1.19(1.22)$ & $18.163(3137)$ \\
\hline \multicolumn{5}{|l|}{ Country } \\
\hline \multicolumn{5}{|l|}{ Cambodia (ref.) } \\
\hline \multirow[t]{3}{*}{ Laos } & Motorcycle & $-1.75(0.46)^{* * *}$ & $-1.09(0.39)^{* *}$ & $-1.637(0.52)^{* *}$ \\
\hline & Car & $0.285(0.52)$ & $0.592(0.46)$ & $-0.447(0.45)$ \\
\hline & Walking/cycling & $-0.511(0.73)$ & $-1.054(0.67)$ & $-17.478(5596)$ \\
\hline \multicolumn{5}{|l|}{ Resident } \\
\hline \multicolumn{5}{|l|}{ City (ref.) } \\
\hline \multirow[t]{3}{*}{ Town/rural area } & Motorcycle & $-1.103(0.41)^{* *}$ & - & - \\
\hline & Car & $-1.225(0.48)^{*}$ & - & - \\
\hline & Walking/cycling & $0.356(0.69)$ & - & - \\
\hline \multicolumn{5}{|l|}{ Distance } \\
\hline \multicolumn{5}{|l|}{ Less than 5 km (ref.) } \\
\hline \multirow[t]{3}{*}{ More than $10 \mathrm{~km}$} & Motorcycle & $-0.189(0.48)$ & - & - \\
\hline & Car & $-0.202(0.54)$ & - & - \\
\hline & Walking/cycling & $-1.804(1.19)$ & - & - \\
\hline \multicolumn{5}{|l|}{ Summary of model fit } \\
\hline Log-Likelihood & & -191.34 & -217.57 & -165.82 \\
\hline McFadden $\mathrm{R}^{2}$ & & 0.2814 & 0.2013 & 0.1491 \\
\hline Likelihood ratio test & & chisq $=149.88$ & chisq $=109.7$ & chisq $=58.122$ \\
\hline
\end{tabular}

ref.: Reference

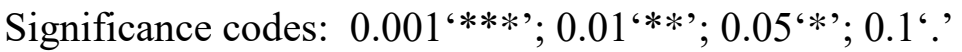

No travel choice is used as the reference category for the three models. 


\section{Evidence from Cambodia and Laos to Curb the COVID-19 Epidemic}

In Cambodia, the public bus, three-wheeler, and motor-taxi are popular among the nonprivate transport modes before the COVID-19 outbreak. The three-wheeler and motor-taxi are the paratransit modes. The public bus system is only operated in Phnom Penh, the capital city, since 2014, and there is no public bus system in other cities or provincial towns. The bus fare is 1,500 KHR (or 0.375 US\$) for one trip, and it is free of charge for students, children, senior citizens, Buddhist monks, and people with disabilities. There was also a twoyear free-ride policy for the garment workers since August 2017. Correspondingly, the public bus is popular in the capital city. There were 6,400 bus users per year on average from 15 September 2014 to 17 April 2016, and 40\% of all the passengers were free riders [31]. The number of daily passengers increased sharply from 7,000 in 2017 to roughly 30,000 in 2019 [32]. Shortly after the first confirmed COVID-19 case was reported, the public bus in the capital city was temporarily suspended since 27 March 2020 for the reason of preventing the spread of COVID-19 in Phnom Penh. Phnom Penh City Bus (PPCB) authority prepared the strategies to prevent and minimize the risk of COVID-19 infection for bus drivers and passengers once operations resume, and only $50 \%$ of bus occupancy rate in terms of passengers are allowed to comply with social distancing guidelines advised by the Ministry of Health [31]. Therefore, the COVID-19 outbreak changes travel behavior in Cambodia, specifically in the capital city.

During the pre-COVID-19 pandemic outbreak in Laos, Tuk-Tuk or Jumbo (threewheeler) and Songthaew (a passenger vehicle modified from a pick-up truck) are popular for passenger mobility in some major cities, such as Vientiane, Luang Prabang, and Pakse, mainly on account of low fares. The typical fare per trip in the cities for Tuk-Tuk is about 50,000 Kip (or 6.25 US\$), and Songthaew has a lower fare than Tuk-Tuk, approximately $10,000-20,000 \mathrm{Kip}$ (or 1.25 - 2.50 US\$) for one trip because of sharing seats with other passengers [32]. Most foreign businesspeople in Vientiane use taxis for a trip or a day. The cost of traveling within a city is typically from 280,000 to $400,000 \mathrm{Kip}$ (or 35 to 50 US\$) all day [33]. Moreover, most people use motorcycles for short distances, and the number of motorcycles increases by over $20 \%$ per year [34]. The buses are mostly used for long-haul intercity travel because of low fares [34]. After there are confirmed COVID-19 cases in Laos, the Ministry of Labour and Social Welfare (MoLSW) and the International Organization for Migration (IOM) officially launched a campaign of bus operation to prevent the spread of COVID-19 disease on public transport in Vientiane from September to mid-November with five routes covered in Vientiane, and about 1,970 passengers use the public buses per day, according to the statistics of the Vientiane Capital State Bus Enterprise [35]. Many people change their travel patterns by using private vehicles rather than public transport to prevent the spread of COVID-19, specifically in major cities and along the borders in Laos.

As of 23 April 2020, Laos and Cambodia reported 19 and 122 COVID-19 confirmed cases in total, respectively [26] (as shown in Table 6). Things are slowly back in normal; however, people's lifestyle has been changed and never been the same to the preCOVID-19 period. Specifically, people used private transport modes rather than public transport modes. Regarding the WHO's reports of the COVID-19 disease, the spread of the virus is very slow and can be controlled by the governments of Laos and Cambodia. This may be thanks to many reasons, e.g., trade activities, industry, tourism, geography, weather, culture, demography, population density, travel behavior, governmental policies and 
strategies, and participation of people to fight against the pandemic. Because our study covers the travel mode choice, we discuss only the travel behavior. Based on our empirical findings, the majority of Cambodian and Lao people travel to the workplace, market, and hospital by private modes (i.e., motorcycle and car) and active modes (i.e., walking and cycling), and the percentages of travel by bus to the key destinations are ignorable, based on our survey results. Students and unemployed people were more likely to stay at home rather than go to the market and hospital. People with high household incomes and people living in a city were likely to travel to work by car, followed by motorcycle.

The Cambodian government closed schools, some entertainment venues (i.e., karaoke clubs, and movie theaters), and many land borders for human traffic only for a short period [36], while all the factories, shopping malls, markets, salons and barbershops, restaurants, and tourist sites, among others still open. Most of the confirmed cases are the imported cases. That students and unemployed people stay at home contributes to slow down and curb the spread of the COVID-19 disease outbreak. A trend of cumulative confirmed cases become fairly steady in Cambodia [37]. A slight difference from Cambodia, the Lao government closed all the borders (i.e., land border and domestic and international flights), schools, salons, barbershops, all the entertainment venues (i.e., karaoke bars, massage and spa shops, and clubs) [38]. Furthermore, markets, retail and beverage shops, and restaurants are allowed for the provision of takeaway and delivery services only [38]. These lockdown measures could be the reasons that the total confirmed COVID-19 cases in Laos are considerably less than those in Cambodia. However, the forecasted gross domestic product (GDP) growth rate of Cambodia is - 5.5\%, while the GDP of Laos is $-0.5 \%$ in 2020 [39]. Noticeably, the governments of these two countries are successful to curb the spread of the COVID-19 outbreak, as compared to the other ASEAN countries.

Table 6. Reported Cases and Deaths by ASEAN Country on 25 April 2020 [37]

\begin{tabular}{ccccccc}
\hline Ranking & $\begin{array}{c}\text { ASEAN } \\
\text { countries }\end{array}$ & $\begin{array}{c}\text { Total } \\
\text { Cases }\end{array}$ & $\begin{array}{c}\text { Total } \\
\text { deaths }\end{array}$ & $\begin{array}{c}\text { Total } \\
\text { recovered }\end{array}$ & $\begin{array}{c}\text { Active } \\
\text { cases }\end{array}$ & $\begin{array}{c}\text { Tests/ 1M } \\
\text { pop }\end{array}$ \\
\hline 1 & Singapore & 12,693 & 12 & 1,002 & 11,679 & 20,815 \\
2 & Indonesia & 8,607 & 720 & 1,042 & 6,845 & 248 \\
3 & Philippines & 7,294 & 494 & 792 & 6,008 & 742 \\
4 & Malaysia & 5,742 & 98 & 3,762 & 1,882 & 3,923 \\
5 & Thailand & 2,907 & 51 & 2,547 & 309 & 2,043 \\
6 & Vietnam & 270 & 0 & 225 & 45 & 2,119 \\
7 & Myanmar & 144 & 5 & 10 & 129 & 115 \\
8 & Brunei & 138 & 1 & 121 & 16 & 29,455 \\
9 & Cambodia & 122 & 0 & 117 & 5 & 345 \\
10 & Laos & 19 & 0 & 7 & 12 & 228 \\
\hline & Total & $\mathbf{3 9 , 4 8 2}$ & $\mathbf{1 , 5 4 6}$ & $\mathbf{1 , 4 1 1}$ & $\mathbf{9 , 9 0 9}$ & $\mathbf{2 8 , 1 6 2}$ \\
\hline
\end{tabular}

\section{Conclusions and Recommendations}

This study explored determinants of travel mode choice for the three key destinations (i.e., workplace, market, and hospital) in two ASEAN countries with the least confirmed COVID19 cases during the global pandemic, the COVID-19 disease outbreak. The study used the primary data set of 217 observations, and the MNL was applied for data analysis. The highlighted findings are concluded as follows: 
- The proportion of bus/van choice for the three key destinations is very marginal (or ignorable). This travel behavior contributes to slow down and curb the spread of the COVID19 epidemic.

- Males were more likely than females to go to work by motorcycle, followed by car and walking/cycling. Females were more prone to stay at home than go to work.

- Highly-educated people (with Master/Ph.D. degrees) were more inclined to go to work than stay at home. They were most likely to go to the market by walking/cycling, followed by car and motorcycle. It can be explained that Master/Ph.D. holders are well educated and might have high incomes, and therefore, they might afford to own a house near the market and go to market by the active modes.

- Private/industry employees and state officials/public servants had a higher baseline likelihood to go to work, while academics/researchers, self-employed persons, and the jobless/students were more likely to stay at home. The jobless/students were least likely to go to the hospital during the COVID-19 disease outbreak.

- People living in a city were more likely than people living in a town/rural area to travel to work by car, followed by motorcycle.

The indispensable sectors in Cambodia and Laos (e.g., aviation, small and mediumsized enterprises, and factories) normally open to sustain national and household economic activities. However, people's behavior changes were ravaged by the COVID-19 pandemic, and most of them used private transport modes instead of public transport for the reasons of privacy and performance of social distancing. This might change people's lifestyles from here on in even though the spread of the COVID-19 will be ended one day, and the new word as "New Normal" appears after the COVID-19 pandemic, representing the new behavior of human activities, such as the way of living, working, traveling, and social life.

This is the preliminary research on the travel behavior of commuters in two ASEAN countries with the least confirmed COVID-19 cases, i.e., Cambodia and Laos. The governments of these two countries are trying to establish several policies and strategies that are best suited to respond to the ripple effect of the global pandemic. People concern more about their welfare and usually stay at home. Commuters prefer private transportation modes to public transportation modes. It depends on time and the stage of the COVID-19 pandemic that is different from one country to another. There are still many factors and conditions that have to be further explored to understand the current situation of the COVID-19 pandemic deeper until the vaccine will be manufactured. There is a need to investigate the determinants of travel mode choice in the post-COVID-19 outbreak and compare it with the findings during the COVID-19 outbreak. Also, future studies should try to understand how lowincome commuters are satisfied with and affected by the implemented transport policies to curb the COVID-19 pandemic in ASEAN countries to ensure equity in social development. Lastly, it is imperative to explore the impacts of geography, demography, human activities, public transport strategies, economic activities, and governmental strategy implementations on dealing with the pandemic disease.

\section{Acknowledgments}

This work received research funding from AUN/SEED-Net under the project of Special Program for Research Against COVID-19 (SPRAC). The authors are grateful to two anonymous reviewers for their voluntary efforts and expertise to give helpful comments for the previous version of the manuscript. 


\section{References}

[1] World Health Organization (WHO), “Q\&A on Coronaviruses (COVID-19), ” 2020 [Online]. Available: https://www.who.int/news-room/q-a-detail/q-a-coronaviruses. [Accessed: April 2020]

[2] World Health Organization (WHO), "Coronavirus Disease (COVID-19) Pandemic," 2020. [Online]. Available: https://www.who.int/emergencies/diseases/novelcoronavirus-2019. [Accessed: April 2020]

[3] World Health Organization (WHO), "How Does COVID-19 Spread?," 2020. [Online]. Available: https://www.who.int/news-room/q-a-detail/q-a-coronaviruses. [Accessed: April 2020].

[4] M. Rith, and M. Piantanakulchai, "At-home activities and subjective well-being of foreign college students in Thailand during the COVID-19 pandemic outbreak," Walailak Journal of Science and Technology, Vol. 17, No. 9, pp. 1024-1033, 2020.

[5] Google Maps, "Southeast Asia" (n.d.) [Online]. Available: https://www.google.com/maps/place/South+East+Asia/@8.2771451,98.1402585,4z/ data $=$ !3m1!4b1!4m5!3m4!1s0x3233af605e720cd5:0x28a70f18542d1b91!8m2!3d2.2179704!4d115.66283. [Accessed: April 2020]

[6] "Laos Shutters Small Checkpoints on Borders With Vietnam, Cambodia, Citing Coronavirus Spread," Radio Free Asia, March 16, 2020. [Online]. Available: https://www.rfa.org/english/news/laos/checkpoints-03162020164126.html.

[7] Reuters, "Laos Records First Two Coronavirus Cases-Thai Media," The Jerusalem Post, March 24, 2020 [Online]. Available: https://www.jpost.com/BreakingNews/Laos-records-first-two-coronavirus-cases-Thai-Media-622110.

[8] "Laos Goes Into Total Lockdown," Travel Trade Report (TTR Weekly), April 1, 2020. [Online]. Available: https://www.ttrweekly.com/site/2020/04/laos-goes-intototal-lockdown/.

[9] A. Westerman, "With 19 Confirmed COVID-19 Cases And No Deaths, Laos To Loosen Lockdown," National Public Radio (NPR), May 17, 2020. [Online]. Available: $\quad$ https://www.npr.org/sections/coronavirus-liveupdates/2020/05/17/856475752/with-19-confirmed-covid-19-cases-and-no-deathslaos-to-loosen-lockdown.

[10] Worldometer, "Coronavarus Cases in Laos," 2021 [Online]. Available: https://www.worldometers.info/coronavirus/country/laos/. [Accessed: January 2021].

[11] A. Chhengpor, "First Case of Virus Found in Cambodian," Voice of America (VOA), March 7, 2020. [Online]. Available: https://www.voanews.com/sciencehealth/coronavirus-outbreak/first-case-virus-found-cambodian.

[12] "Health Ministry Stops Religious Gatherings," Cambodia News English, March 17, 2020. [Online]. Available: https://cne.wtf/2020/03/17/health-ministry-stopsreligious-gatherings/.

[13] China.org.cn, "Cambodia Sets National Committee to Combat COVID-19," 2020. [Online]. Available: http://www.china.org.cn/world/Off_the_Wire/202003/18/content_75830861.htm. [Accessed: January 2021].

[14] T. Vida, "Cambodia to Impose Travel Restrictions From Tuesday," Khmer Times, March 28, 2020. [Online]. Available: https://www.khmertimeskh.com/706863/cambodia-to-impose-travel-restrictionsfrom-tuesday/.

[15] T. Rinith, "Khmer New Year Holiday Cancelled to Curb Virus Spread," Khmer Times, April 8, 2020. [Online]. Available: https://www.khmertimeskh.com/710769/khmernew-year-holiday-cancelled-to-curb-virus-spread/.

[16] S. David, "Each Laid-off Worker to Get \$70 a Month," Khmer Times, April 8, 2020. 
[Online]. Available: https://www.khmertimeskh.com/710752/each-laid-off-workerto-get-70-a-month/.

[17] P. Vantha, "Garment and Other Workers Going on Holiday Must Get into Quarantine When They Return," Cambodianess, April 9, 2020. [Online]. Available: https://cambodianess.com/article/garment-and-other-workers-going-on-holidaymust-get-into-quarantine-when-they-return.

[18] Worldometer, "Coronavirus Cases in Cambodia," 2020. [Online]. Available: https://www.worldometers.info/coronavirus/country/cambodia/. [Accessed: January 2021].

[19] B. Orme, "Sample size issues for conjoint analysis," In Getting Started with Conjoint Analysis: Strategies for Product Design and Pricing Research, 4th edition, Madison, Wis.: Research Publishers LLC, 2010, pp. 57-65.

[20] K. Molugaram, and S.G. Rao, "Sampling," In Statistical Techniques for Transportation Engineering, K. McCombs, Ed.: Oxford, UK: Joe Hayton, 2017, pp. 331-338.

[21] T. Sotha, "Public Bus And Taxi Boat Services Suspended," Khmer Post, March 27, 2020. [Online]. Available: https://en.khmerpostasia.com/2020/03/27/public-bus-andtaxi-boat-services-suspended/.

[22] Japan Transport Cooperation Association, Overview of Urban Public Transport in Cambodia 2017 [Online]. Available: https://www.researchgate.net/publication/324167687_Overview_of_urban_public_tr ansport_in_Cambodia [Accessed: April 2020]

[23] K.E. Train, Discrete Choice Methods with Simulation, UK: Cambridge University Press, Cambridge, United Kingdom, 2003.

[24] A. Hasan, W. Zhiyu, and A. S. Mahani, "Fast estimation of multinomial logit models: R package mnlogit," Journal of Statistical Software, Vol. 75, 2016.

[25] D.A. Hensher, J.M. Rose, and W.H. Greene, Applied Choice Analysis. Cambridge, UK: Cambridge University Press, 2005.

[26] World Health Organization (WHO), "Coronavirus disease 2019 (COVID-19) Situation Report - 94," 2020. [Online]. Available: https://www.who.int/docs/defaultsource/coronaviruse/situation-reports/20200423-sitrep-94-covid19.pdf?sfvrsn=b8304bf0_4. [Accessed: April 2020].

[27] D. Belsley, Conditioning Diagnostics: Collinearity and Weak Data in Regression. New York: Wiley, 1991.

[28] M. Rith, A.M. Fillone, and J.B.M. Biona, "Development and application of a travel mode choice model and policy implications for home-to-work commuters toward reduction of car trips in metro Manila," Asian Transport Studies, Vol. 5, No. 5, pp. 862-873, 2019.

[29] M. Rith, R.P. Abad, A.M. Fillone, K. Doi, and J.B.M. Biona, "Understanding the impact of urban form attributes on household vehicle ownership and choice in metro manila: Modeling, simulation, and application," Enginerring and Applied Science Research, Vol. 46, No. 3, pp. 238-247, 2019.

[30] M. Rith, A. Fillone, and J.B.M. Biona, "The impact of socioeconomic characteristics and land use patterns on household vehicle ownership and energy consumption in an urban area with insufficient public transport service - A case study of metro Manila," Journal of Transport Geography, Vol. 79, p. 102484, 2019.

[31] S. David, "City Bus prepares steps to resume services," Khmer Times, May 28, 2020. [Online]. Available: https://www.khmertimeskh.com/50727685/city-bus-preparessteps-to-resume-services/.

[32] R. Beach, How to Navigate Transport in Laos [Blog post], May 23, 2018, [Online]. 
Available: https://theculturetrip.com/asia/laos/articles/how-to-navigate-transport-inlaos/. [Accessed: February 2021].

[33] Lonely Planet, "Local Transport," 2021. [Online]. Available: https://www.lonelyplanet.com/laos/narratives/practicalinformation/transport/getting-around/local-transport. [Accessed: February 2021].

[34] Facts and Details, "Transportation in Laos: Motorbikes, new roads, and friendship bridges," 2019. [Online]. Available: http://factsanddetails.com/southeastasia/Laos/sub5_3d/entry-2984.html. [Accessed: February 2021].

[35] International Organization for Migration, "IOM, Lao Ministry of Labour and Social Welfare Bus Campaign to Promote COVID19 and Safe Migration Messaging," 2020.

[36] "Cambodia closes karaoke clubs, cinemas to curb outbreak," TheStar, March 17, 2020. [Online].

Available: https://www.thestar.com.my/news/regional/2020/03/17/cambodia-closes-karaokeclubs-cinemas-to-curb-outbreak.

[37] Worldometer, "COVID-19 Coronavirus Pandemic," 2020. [Online]. Available: https://www.worldometers.info/coronavirus/. [Accessed: April 2020].

[38] Tilleke \& Gibbins, "Laos Imposes Sweeping COVID-19 Lockdown Measures,” 2020. [Online]. Available: https://www.tilleke.com/resources/laos-imposes-sweepingcovid-19-lockdown-measures. [Accessed: April 2020].

[39] Asian Development Bank (ADB), "Comparative economic forecasts," $A D B, 2020$. [Online].Available: https://www.adb.org/countries/thailand/economy. [Accessed: July 2020]. 